\title{
Chemical monitoring of the socio-ecological situation in resource-producing regions
}

\author{
Daniela Marasova ${ }^{1}$, Vladimir Zolotukhin ${ }^{2}$, Natalia Zolotukhina ${ }^{2}$, Olga Volkova $^{3}$, and \\ Mariya Yazevich $^{2}$ \\ ${ }^{1}$ Technical University of Kosice, Faculty of Mining, Ecology, Process Control and \\ Geotechnologies, 042 00, Kosice, Kosice, Lrtna str., 9, Slovakia \\ 2 T.F. Gorbachev Kuzbass State Technical University, Department of History, Philosophy and Social \\ Sciences, 650000 Kemerovo, 28 Vesennyaya st., Russian Federation \\ 3 CJSC "Tokem", engineer of 1 category 650000 Kemerovo, Karbolitovskaya, 1/2, Russian \\ Federation
}

\begin{abstract}
The article examines the problems associated with the environmental situation in resource-producing regions, the causes of which are associated with air pollution, soil, water bodies, etc. as a result of human activity, waste from industrial, including coal enterprises. To reduce the negative impact on these processes, as well as to control the ecological state, it is necessary to monitor, including from the chemical point of view, the dynamics of changes in the state of the environment, as well as its impact on a person, his life activity and the surrounding social infrastructure. We are talking about the degree of influence of the level of pollution on human health, on the quality of food consumed and industrial production, which ultimately has a significant impact on the quality of life and demographic processes at the regional level. The necessity of constant chemical monitoring of the composition of the atmospheric air of industrial cities, which is affected by human economic activity, is emphasized. This is especially true for the coal industry, depending on its distance from industrial centers, the state of treatment facilities and socio-economic opportunities for the use and application of "green" technologies. The use of scrubbers ("wet") ash collectors, traditional methods of water treatment, including the use of settling tanks and filter treatment facilities at coal mining enterprises, etc. contribute to the use of cleaning products for the reclamation of land disturbed by coal mines as a result of economic activities. Environmental policy should be implemented in accordance with the regional environmental standard adopted in the Kemerovo Region as part of the development strategy until 2035 and aimed at ensuring environmental-oriented and energy-efficient economic growth.
\end{abstract}

* Corresponding author: zvm64@mail.ru 


\section{Introduction}

In industrial regions where there is an intense impact on the environment of the economic activities of mining enterprises (mines, mines, processing plants), chemical enterprises, urban planning, transport communications, etc., the concentrations of harmful substances in the air are subject to sharp fluctuations and depend on the technological regime, the state of the equipment, temperature and other factors. In order to comply with federal and regional environmental standards [1, 2], including under the program "Clean Coal - Clean Kuzbass" [3], it is necessary to constantly carry out environmental monitoring in order to identify the most toxic substances from the variety, determine the source and their quantitative content. For this purpose, there is a chemical monitoring of the composition of atmospheric air, which allows you to control the level of environmental pollution, compliance with the quality standards of environmental components (atmospheric air, surface and underground water, soil) and timely make organizational and managerial decisions to minimize socioeconomic, biomedical and other risks to the population in resource-producing regions.

\section{Material and Method}

As part of the Kemerovo Region development strategy, the prospects for the development of the coal industry are being evaluated, taking into account the transition to the use of the best available technologies. At the same time, various methods are used, including the use of scrubbers ("wet") ash collectors, as a result of which it is possible to use them for the reclamation of land disturbed by coal miners as a result of economic activities. Methods related to the use of settling tanks and filter treatment facilities and traditional methods of water treatment under various technological conditions, including the discharge of contaminated water into reservoirs due to seasonal fluctuations, were also used. An important aspect is the implementation of control and production control of sources of emissions of pollutants into the atmospheric air by independent accredited laboratories.

\section{Results and Discussion}

In industrial cities, the air is polluted by a complex mixture of substances, the composition of which depends on the nature of production, their territorial location, the concentration of harmful substances in the air, are subject to sharp fluctuations and depend on the technological regime, the state of the equipment, temperature and other factors. According to the State report "On the state and Environmental Protection of the Russian Federation in 2019", in the Kemerovo Region, "in the structure of emissions of pollutants into the atmosphere from stationary sources in 2019, compared to 2018, there is an increase in emissions of solid substances (by 11.4\%), carbon monoxide (by $13.1 \%$ ), sulfur dioxide (by $4.3 \%$ ), nitrogen oxide (by $26.6 \%$ ), VOCs (by 2.87 times) [4, P. 735]. From this point of view, there are economic [5], socio-environmental [6], demographic [7], migration [8] and other risks for regional development and the disclosure of human potential. In accordance with the "dynamics of the main characteristics of the state environmental supervision carried out by the Rosprirodnadzor system (Federal Service for Supervision of Natural Resources Management) in the Russian Federation, 2015-2019", such an indicator as "on the occurrence of a threat of harm to the life, health of citizens, harm to animals, plants, the environment, objects of cultural heritage (historical and cultural monuments) of the peoples of the Russian Federation, state security, as well as the threat of natural and man - made emergencies" was checked 517 times in 2015, and 331 in 2019. At the same time, the indicator "on causing harm to the life and health of citizens, harm to animals, plants, the 
environment, objects of cultural heritage (historical and cultural monuments) of the peoples of the Russian Federation, property of individuals and legal entities, state security, as well as the occurrence of natural and man-made emergencies" increased from 105 times in 2015 to 141 in 2029" [4, P. 864].

To determine the reliable degree of pollution from a variety of substances, because the air is a colloidal system consisting of suspended particles, liquid droplets entering the air, it is necessary to identify the most toxic and determine their quantitative content. For this purpose, there is a chemical monitoring of the composition of the atmospheric air in industrial centers. It helps to monitor the state of the air environment, its pollution and predict the future state.

The main sources of pollution are thermal power plants, processing (concentrating) plants, metallurgical plants, and road transport. Metallurgical, cement and magnesite plants emit dust and sulfur gases into the atmosphere. In non-ferrous metallurgy, when producing metallic aluminum by electrolysis with waste gases from electrolysis baths, a significant amount of gaseous and pulverized fluoride compounds is released into the atmospheric air. Air emissions from the oil and petrochemical industries contain a large amount of hydrocarbons and hydrogen sulfide. The main emissions from the chemical industry are oxides of carbon, nitrogen, sulfur, ammonia, hydrogen sulfide, chlorine and fluoride compounds, etc.

Based on the reports on the state and environmental protection of the Kemerovo Region for 2017-2019 [9], it is possible to trace the dynamics of changes in the composition of the atmospheric air of the city of Kemerovo (Table 1.) based on data from the South Siberian Interregional Department of Rosprirodnadzor (Federal Service for Supervision of Natural Resources Management).

Table 1. Dynamics of mass emissions of pollutants into the atmospheric air, thousand tons

\begin{tabular}{|c|c|c|c|}
\hline \multirow{2}{*}{$\begin{array}{c}\text { Name of the } \\
\text { contaminant }\end{array}$} & \multicolumn{3}{|c|}{ Mass of emissions by year, thousand tons } \\
\cline { 2 - 4 } & $\mathbf{2 0 1 7}$ & $\mathbf{2 0 1 8}$ & $\mathbf{2 0 1 9}$ \\
\hline Solid & 33,74 & 28,50 & 45,21 \\
\hline $\begin{array}{c}\text { Nitrogen } \\
\text { oxides }\end{array}$ & 10,03 & 8,57 & 10,83 \\
\hline $\begin{array}{c}\text { Sulfur } \\
\text { dioxide }\end{array}$ & 14,57 & 9,24 & 14,36 \\
\hline $\begin{array}{c}\text { Carbon } \\
\text { monoxide }\end{array}$ & 6,96 & 8,36 & 16,03 \\
\hline $\begin{array}{c}\text { Volatile } \\
\text { organic } \\
\text { compounds }\end{array}$ & 1,28 & 0,99 & 1,54 \\
\hline $\begin{array}{c}\text { Total } \\
\text { emissions }\end{array}$ & 41,11 & 36,11 & 55,83 \\
\hline
\end{tabular}

Road transport accounts for the bulk of harmful emissions. One of the reasons for this is the lack of an automobile catalyst, another reason and the most important is the low quality 
of domestic gasoline produced. The exhaust gases contain unburned or not completely burned hydrocarbons.

A significant share in the total mass of urban emissions into the atmosphere is made up of gaseous and liquid substances - 45,212 thousand tons $(80.98 \%)$. The greatest danger to humans is smog, which is a mixture of smoke, fog and dust, one of the types of air pollution in large cities and industrial centers. Smog can form under almost any natural and climatic conditions. The most harmful smog is in calm weather, when the vertical circulation of air masses stops in the upper layers of the air. The fog itself is not dangerous to the human body, but it becomes harmful only when it is extremely polluted with toxic impurities [10].

Since air pollution has a harmful effect in several ways (the ingress of harmful emissions into the respiratory system of living organisms; an increase in the acidity of atmospheric precipitation, which affects changes in the chemical composition of soils and water [11]; the formation of a greenhouse effect), it must be stated that "the total use of fresh water in 2019 was 1513.02 million $\mathrm{m} 3$, which is $0.7 \%$ less than in 2018 , and $13.5 \%$ less than in 2010. Most of the water in 2019 was used for production needs - 1266.83 million $\mathrm{m} 3$, for drinking and household needs - 177.77 million $\mathrm{m} 3$, for other needs 65.89 million $\mathrm{m} 3$, for agriculture -1.93 million $\mathrm{m} 3$. Household water consumption per capita in 2019 was $66 \mathrm{~m} 3$ / year per person, which is $7.0 \%$ less than in 2018, and 7.6 times more than in 2010" [3]. This situation makes it necessary to change the consciousness of both a person [12], as authorities at all levels and representatives of the business elite, as well as ideological approaches to the use of "green" technologies [13] in the economic activities of not only industry, but also coal enterprises, including in the field of technological water purification [14] and restoration, environmental rehabilitation of water bodies that have lost the ability to self-clean, as well as improving their environmental condition. It should be noted that on the territory of the Kemerovo region, there is also a high level of discharge of pollutants into surface water bodies, caused by high wear and tear of structures and the use of outdated production and cleaning technologies, as well as the illegitimate use of surface water bodies.

To obtain a reliable assessment of air pollution, atmospheric air monitoring is used, which allows you to monitor the state of the air, its pollution, as well as to evaluate and predict further options. When identifying the degree of pollution, it is necessary to determine the estimated cost, as well as check its reliability for carrying out work to eliminate the consequences of pollution, including accumulated environmental damage.

Within the framework of the State program "Ecology, Subsurface Use and Rational Water Use" for 2017-2024, implemented in the Kemerovo region, it is planned to reduce the total anthropogenic load on the environment, including reducing the total volume of emissions of harmful (polluting) substances into the atmospheric air by 69.03 thousand tons $(20.25 \%)$ in the city of Novokuznetsk by 31.12 .2024 (from "very high" to "increased"). Novokuznetsk is included in the list of the most polluted cities in Russia. "According to observations in 2019, the increased level of atmospheric air pollution in the Prokopyevsk city district was estimated by the content of dust (suspended substances); the high level of pollution in the city of Kemerovo and very high in the city of Novokuznetsk - by the content of benzopyrene" [3].

At the enterprises of the city of Kemerovo, various measures are constantly carried out to reduce the negative impact on the atmospheric air and contribute to the formation of a favorable environmental situation. These include: maintaining a database of emissions from enterprises and road transport; analyzing emissions by component composition and their concentration; identifying enterprises responsible for excess air pollution and recommendations for reducing it; and maintaining a database of chemical monitoring results. 
As part of the measures to improve the environmental situation, a number of measures were carried out. In particular, PJSC "Koks" has launched a complex of coke ovens without capturing chemical products of coking, in order to increase the productivity and efficiency of dust collection (the planned reduction in emissions of inorganic $\mathrm{SiO} 2$ dust - not more $20 \%$ by 14.2 tons). The existing gas and dust collection equipment of the coal preparation and coke shop has been upgraded, with a cleaning efficiency of up to $99 \%$.

Kemerovo JSC "Azot" has equipped the emission sources of the "Ammonia-1" and "Ammonia-2" workshops with an automated emission control system to control the impact on the atmospheric air in a continuous automatic mode. The technical re-equipment of the boiler burner devices in the "Ammonia-2" workshop allowed to reduce the emissions of nitrogen oxides and ammonia. The reconstruction of the sulfurous anhydride and sulfuric acid mist capture system in the sulfuric acid shop increased the degree of purification from sulfur dioxide emissions.

The LLC "Khimprom" in the production of propylene oxide has carried out control of emissions of pollutants into the atmosphere.

Every year, a huge amount of harmful substances from gases and dust enters the atmospheric air. Currently, a common way to control air pollution is to remove pollutants from the release site. This is carried out by the construction of high pipes in factories and heat stations, the installation of filters, gas and dust collectors. However, all these methods cannot solve the problem as a whole. The accumulation of harmful substances is not captured properly and still gets into the atmospheric air. Therefore, in our opinion, we need a set of measures aimed at changing the attitude of society to the problems of environmental pollution (atmospheric air, water resources), without which technological changes in this area are impossible.

\section{Conclusion}

In order to effectively solve environmental problems, create a safe and comfortable environment in the places where the population lives, it is necessary to carry out various types of monitoring, including chemical monitoring to detect the degree of pollution of not only atmospheric air. In modern conditions, reliable information about their conduct and results is in demand by public authorities, various sectors of the economy and the public. The lack of information about the real state and compliance for the safe life of a person is perceived negatively, with distrust, which is a condition for the emergence of social tension. The degree of the latter depends on the formation of a scientifically based state policy in the field of environmental protection, the forecast of the development of the regional mineral resource base, methods and methods of its use to ensure a decent quality of life for the population, taking into account the demographic situation [15]. An important aspect is also the formation of the ecological culture of the population [16], which is necessary for changing the responsible attitude of a person to the environment and the availability of knowledge and the desire to cooperate with others in solving environmental problems.

\section{References}

1. Resolution of the Government of the Russian Federation of 24.12.2019 No. 1806 "On the creation and operation of the Federal State Information system for monitoring the quality of atmospheric air in the urban districts of Bratsk, Krasnoyarsk, Lipetsk, Magnitogorsk, Mednogorsk, Nizhny Tagil, Novokuznetsk, Norilsk, Omsk, 
Chelyabinsk, Cherepovets and Chita" [Electronic resource]. Access mode: http://www.consultant.ru/document/cons_doc_LAW_341824/

2. Order of the Ministry of Natural Resources and Ecology of the Russian Federation No. 814 dated 29.11.2019 "On Approval of the Rules for Quotas for emissions of pollutants (except for radioactive substances) into the Atmospheric air" (registered with the Ministry of Justice of the Russian Federation No. 56956 on 24.12.2019) Information and Legal portal "Garant" [Electronic resource]. Access mode: http://base.garant.ru/73340414/

3. On the approval of the state program of the Kemerovo Region - Kuzbass "Ecology, subsoil use and rational water use" for 2017-2024, Resolution of the Board of the Administration of the Kemerovo Region of September 16, 2016 N 362 (as amended on December 25, 2020)

https://docs.cntd.ru/document/441678826

[Electronic resource].

4. On the state and environmental protection of the Russian Federation in 2019 (Moscow, Ministry of Natural Resources of Russia; Lomonosov Moscow State University, 2020)

5. S. Grigashkina, T. Galanina, V. Mikhailov, T. Koroleva, E. Trush, E3S Web Of Conferences, 02001 (2017)

6. S. Kovalevsky, N. Ravochkin, V. Shchennikov, E3S Web of Conferences, 41, 04035 (2018)

7. N. Zolotukhina, , V. Zolotukhin, M. Yazevich, D. Marasova, A. Tarasenko, E3S Web of Conferences, IIMS, 174, 18, 04056 (2020)

8. E. O. Gavrilov, O. F. Gavrilov, E. F. Kazakov, Metamorphoses of Religion and the Human in the Modern World Smart Innovation, Systems and Technologies, 716 (2019)

9. Report "On the state and environmental protection of the Kemerovo region - Kuzbass in 2019". Kemerovo, 2020, Department of Natural Resources and Ecology of the Kemerovo Region, http://ecokem.ru/wp-content/uploads/2020/02/doclad_2019.pdf

10. B. Nebel, Environmental Science. How the world works (Moscow, Mir, 2017)

11. O. I. Volkova, N. A. Zolotukhina, V. M. Zolotukhin, M. Y. Yazevich, IOP Conf. Ser.: Earth Environ. Sci., 543012012 (2020)

12. M. Yazevich, O. Kalinina, O. Zhironkina, E3S Web of Conferences 134, 03004 (2019)

13. T. Gvozdkova, M. Tyulenev, S. Zhironkin, V. Trifonov, Yu. Osipov, "Ecology and Safety in the Technosphere: Current Problems and Solutions", 012010 (2017)

14. M. Tyulenev, A. Khoreshok, E. Garina, O. Litvin, Y. Litvin, E. Maliukhina, "Ecology and Safety in the Technosphere: Current Problems and Solutions", 012035 (2017)

15. S. V. Soboleva, N. E. Smirnova, O.V. Chudaeva, Regional Research of Russia, 10(2), $220(2020)$

16. N. Ravochkin, V. Shchennikov, V. Syrov, E3S Web of Conferences (2017) 